\title{
Does Pragmatism Have A Theory of Power?
}

Joel Wolfe

\section{OpenEdition}

\section{Journals}

Electronic version

URL: http://journals.openedition.org/ejpap/775

DOI: 10.4000/ejpap.775

ISSN: 2036-4091

Publisher

Associazione Pragma

\section{Electronic reference}

Joel Wolfe, « Does Pragmatism Have A Theory of Power? », European Journal of Pragmatism and American Philosophy [Online], IV - 1 | 2012, Online since 23 July 2012, connection on 19 April 2019. URL : http://journals.openedition.org/ejpap/775; DOI : 10.4000/ejpap.775

This text was automatically generated on 19 April 2019

\section{(c) $(1)$}

Author retains copyright and grants the European Journal of Pragmatism and American Philosophy right of first publication with the work simultaneously licensed under a Creative Commons AttributionNonCommercial-NoDerivatives 4.0 International License. 


\title{
Does Pragmatism Have A Theory of Power?
}

\author{
Joel Wolfe
}

1 Power is one of the key concepts in the social sciences (Clegg \& Haugaard 2009: 1; Stoker 2010: 19). In political science, concepts of power have a long and rich heritage, from Machiavelli and Hobbes to Robert Dahl, Steven Lukes, Michael Mann, and Michel Foucault. Usage of the concept indeed pervades political science, though the scholarship that explicitly discusses a concept of power is small in comparison to studies of political phenomena that use implicit and unexamined notions of power.

2 Attempts to classify these usages into analytical traditions point to the importance of various meta-theoretical traditions in determining the meaning of the concept of power. Stewart Clegg (1989) highlights the agency, disposition, and facilitative conceptions of power, linking them to Hobbesian and Machiavellian traditions in political thought. In a not dissimilar vein, Mark Haugaard (2002: 2-4) points to four "language games" commonly used to analyze power: the analytical conceptual type clarifying terms, the non-conceptual type adopting notions that fit research purposes (agency), modern social theory (dispositional) and postmodern social theory (facilitative). What is notable about these characterizations is that the different approaches to power reflect the philosophical traditions of empiricism, realism, and interpretism. Visions of power, in short, develop from different theoretical starting points.

3 The absence of recognition of pragmatism's contribution to conceptions of power stands out. Its contribution to the social sciences was substantial during the first decades of the twentieth century in America, influencing the progressive movement, debates about democracy, the sociology of the Chicago school, the symbolic interactionism of Herbert Blumer, and the institutional economics tradition of T.B. Veblen, J. R. Commons, and J. K. Galbraith. It then lost its impetus from WW II until a revival in the 1990s (Wolfe 1998; Baert 2003; Mancias 1998). Today pragmatism inspires and animates a growing movement among philosophers and social scientists. 
4 Furthermore, pragmatism is often accused on ignoring the analysis of power or even worse assumes a view of power that is overly idealistic and airy fairy. Dewey's emphasis on consensus, cooperation, and social improvement may at first seem vulnerable to such interpretations. Critics charge that pragmatism is simply naive about power. Typical is C. Wright Mills' claim that John Dewey's focus on discussion and consensus ignores the reality of conflict over values and elite domination. Similarly, John Diggins (1994: ch 7) rebukes Dewey for refusing to discuss power and seeing it as an aberration. Even the prominent pragmatist social theorist Han Joas writes that "it may be true - as many critics say - that pragmatism is in need of a theory of power" (Joas 1998: 194).

Efforts to challenge this negative claim are few. One is Roudy Hildred's (2009) article, "Reconstructing Dewey on Power," in which he presents a well-argued case debunking the idea that Dewey ignored power. After thoroughly surveying those denouncing Dewey, Hildred elaborates how key Deweyan concepts implicitly contain a concept of power. His careful analysis concludes that Dewey's view of power is a complex version of the agency notion of power as capacity, the probability of an agent imposing her will against resistance, enriched by consideration of "social customs and habits, and relative to the transactional fields of experience" (Hildred 2009: 782, 799). This interpretation sees Dewey as consistent with the widely accepted agency conception of power, often identified with Max Weber (1958: 180) and Robert Dahl (1968).

A second is my own article, "Power: A Pragmatist View" (Wolfe 2002). This agrees that Dewey's philosophy implicitly contains a concept of power but argues that Dewey's pragmatism offers multiple views of power. Dewey's most basic idea of power, I explain, refers to making differences through conjoint action within a social medium. Only when such effective social practices are absent is it possible to identify power as interactional instances of conflict between wills, structures, or expertise. Developing this distinction, I identify two types of power: power as indirect or intrinsic to social media and as direct or manifesting traits of pressure and resistant, facilitation and constraint.

7 To elaborate the thesis that Dewey's pragmatism implicitly formulates an analysis of power that centers on an indirect, intrinsic or transactional conception and entails distinguishing different types of power involves the following steps. First, the discussion shows how Dewey's philosophical perspective provides a theory of praxis that is in essence a tacit theory of power. Second, the account shows how Dewey's theory of praxis provides for distinguishing different modes or types of power. A third section considers how Dewey's approach to power offers tools for determining the distribution of power. A final part highlights the implications of Dewey's viewpoint for contemporary analyses of power.

\section{Pragmatism and Praxis}

8 A pragmatist framework of inquiry views human beings as participants and experimenters in a community of inquiry, breaking with the Cartesian tradition that sees humans as "spectators" discovering foundations and then deriving more complex knowledge from these foundations. "Man as agent comes into the foreground here because human agency is the key for understanding all aspects of human life, including human inquiry and knowledge" (Bernstein 1971: 177). Action and creativity become the 
central theme, with knowledge both depending on action and guiding action in difference making (Joas 1996).

The turn to praxis or human activity follows from Dewey's empirical instrumentalism. His pragmatist starting point turns foundationalism upside down; it makes ontology result from inquiry and inquiry follows from concrete problems (Sleeper 2001: 119-21). Instead of drawing implications from abstract premises, pragmatism starts with experience and thereafter moves on with the struggle to interpret and control it. Felt qualities are had as experiences from within and do not originate from predefined notions (Hildebrand 2003: 188-90). Rather doubts or problems that arise need to be denoted first and examined for possible solutions and decisions.

10 The pragmatic starting point rejects philosophical foundationalism, dualism, and reductionism. Tests of knowledge are to be found in the consequences of human activity rather than predetermined by prior conceptual strategy independent of the actual exercise of power. Knowledge cannot be defined or measured by conceptual fiat, determined by either objective or subjective foundations. This, in short, rejects traditional Cartesian epistemology in which the mind is a spectator, or "great mirror, containing various representations - some accurate, some not - and capable of being studied by pure, nonempirical methods" (Rorty 1979: 12).

11 Instead, Dewey's empirical method holds that knowledge results from actively engaging an empirical dilemma, through an ongoing process "of working back and forth between the larger and the narrower fields, transforming every increment upon one side into a method of work upon the other, and thereby testing it" (MW 2: 316; cited in Ratner 1939: 56). To have an experience is to start with a problematic situation, a noncognitive and qualitative issue, and after that to define and redefine it until a solution is found. Starting from pure experience is impossible and starting with a theoretical tool restricts the scope of what is found. The empirical method consequently is a genetic method in which knowledge emerges from a "working back and forth between the technical study of the intellectualized problems of philosophy and the common world of experience, the sociocultural conditions and activities, including the scientific, which generate or are those problems (Ratner 1939: 56; Ratner's italics). In contrast to the givens of the empiricist, pragmatism turns observable sense data into interpretations, "the products of reflective discrimination, while the situation from which they are discriminated is not" (Hildebrand 2003: 186). As Ira Cohen states (2000: 86), "(Dewey's) theory of praxis is not so much a theory of habit as a theory of cycles of habit, reflective, rational consciousness, and behavioral change."

Dewey's philosophic method for accumulating and correcting knowledge, moreover, allows for elucidating praxis in terms of three overlapping spheres of analysis. Originally articulated in Dewey's Studies in Logical Theory (MW 2: 298-315) and highlighted by Joseph Ratner (1939: 49-50), these intertwined dimensions within Deweyan pragmatism are logic, modes of experience, and the social world giving rise to problems. The contemporary pragmatist sociologist Hans Joas conceptualizes action similarly, as involving three elements of analysis - intentionality, corporeality, and sociality (Joas 1996: 145-95; Jung 2010). Such elements hence provide the key dimensions for a pragmatist analysis of operations for the making of differences, the informed action or praxis of social agents effecting solutions to problematic situations. 

aiming to solve a specific problem and a concluding judgment or action that makes a difference by reconstructing a qualitative situation. This replaces the traditional dualism by proposing that knowledge results from solving problems through the application of the doubt-inquiry sequence in which agents make inferences and put their judgments to the test. All knowledge correspondingly is like other types of human activities, such as medicine or farming, in being practical adaptations to concrete problems. Viewing inquiry as organic functioning prevents fixing distinctions between superior and inferior causes and makes practical activities of examining inferences through experimentation the source of productive knowledge (Hildebrand 2008: 49). The knower is a participant in the public processes of inquiry, and human agency takes the leading role in creating knowledge and understanding human existence. Darnell Rucker (1977: xiv) summarizes Dewey's position: “Knowing, whatever its level of abstraction or precision of statement, has its roots in human activity, and its being as knowledge depends upon the continual renewal of contact with that activity." for Certainty points to the historic turn to the practice of experimentation as a superior tool for warranting knowledge. Dewey sees the start of the scientific revolution in Galileo's move away from grounding knowledge in contemplative enjoyment of fixed entities to the conscious and deliberate engagement and control of relations among existences (LW 4: 76). According to Dewey, experimental methods are distinguished by three transitive activities.

The first is the obvious one that all experimentation involves overt doing, the making of definite changes in the environment or in our relation to it. The second is the agent's use of ideas so that experiment is not a random activity, rather it is directed by ideas which have to meet the condition set by the need of the problem inducing the active inquiry. The third feature, in which the other two receive their full measure of meaning, is that the outcome of the directed activity is the construction of a new empirical situation in which objects are differently related to one another, and such that the consequences of directed operations form the objects that have the property of being known. (LW 4: 70)

Dewey's second key philosophical element for difference making is experience. In his "Need for the Recovery of Philosophy," Dewey sets out his conception of experience by pointing to five contrasts with its traditional meaning. Instead of being a knowledge affair, experience denotes all modes of interaction between organism and environment; instead of being primarily subjective, the subject and object relations are functional distinctions arising from ongoing experience; instead of centering experience on the present or the past, it is forward looking; instead of consisting of discrete particulars, experience is constructed through transactions; and instead of being separated from reason, experience entails the future, the reconstitution of the present into a different situation (MW 10; Hildebrand 2003: 36). Experience denotes the praxis of agents' doings and undergoings within unsettled situations and in accordance with socially learned responses or habits, impelling problem solving and creativity.

The central concepts of inquiry and experience link to the third area situating praxis, the social and natural world that gives rise to problems. The construction of order, as people move within and through various frames of discourses and action, resolves the uncertainty that cannot be appreciated by reducing it to sense data or to dyadic links 
between such data. Dewey clarifies that the "ultimate value of the logic of experience" is resolution of social problems:

The right relationship and adjustment of the various typical phases of experience to one another is a problem felt in every department of life. [...] It may be that general logic cannot become an instrument in the immediate direction of the activities of science or art or industry; but it is of value in criticizing and organizing tools for immediate research. It also has direct significance in the valuation for social or lifepurposes of results achieved in particular branches. (MW 2: 313)

the notion of the isolated individual, gives primacy to socially encumbered actors responding to and regenerating their social medium. Individuals are not fixed essences but authors of culturally specific acts learned from and appropriate to the social context. Social connections among people provide the opportunities and means for carrying out societal purposes, whereas the self is in fact a social being formed within and through participation in various social media. In Human Nature and Conduct (1922), Dewey elaborates on the social character of human conduct, drawing on the three overlapping dimensions - a medium of learned practices or habits, the impulse or live energy, and intelligence from inquiry-based judgment - to conceptualize action or praxis.

In sum, Dewey's philosophical starting point centers on praxis and the ways human action makes differences within and through a social medium, in effect furnishing a tacit theory of power. His approach to theorizing action through concepts of experience, inquiry, and the environment, with ideas mediating and regulating how and why transactions generating a cooperative instrumentality occur, moves away from standard interactive or dyadic approaches to power. In developing the Darwinian model of organism and environment into a theory of intelligent action, he presages a cybernetic vision, by transforming a biological metaphor into one of modes of communication and social control (Johnson 2010; Burke 1994; Gardner 1985). As Ira Cohen (2000: 84) clarifies, "if action refers to what actors mean, or intend by what they do, praxis refers to how actors make what they do happen," emphasizing the role of habits and inquiry in directing practices within and through the unfolding of the social medium. Controlling what happens is critical to pragmatism's active search for meliorism. Philip Jackson (2006: 65) underscores how central to this is to Dewey's philosophical achievement, citing 
Dewey's reflection that his ambition was to have "knowledge turned to account in the instruction and guidance it may convey in piloting life through the storms and the shoals that beset life-experience as well as into such havens of consummatory experience as enrich our human life from time to time" (LW 16: 389).

\section{Praxis and Types of Power}

21 Dewey's analysis of praxis in terms of how agents make differences and how they do so in order to control future events provides the basis for arguing that his pragmatism contains a theory of power. Accepting this analysis entails a view of making differences or power that centers on "power within" a social medium, while making provision for understanding other types of power. Showing that the theory of praxis establishes a transactional view of power will allow for differentiating it from inter-actional and selfactional conceptions.

The framework of analysis that Dewey and Bentley present in Knowing and the Known to formulate concepts that advance pragmatism and science also provides an analogy for assessing the contributions of the debates about power. They name self-action, interaction and transaction as three levels of the organization and presentation of inquiry that denote "all human behaviors in and with respect to the world, and [...] are all presentations of the world itself as men report it" (LW 16: 100-1; Lavine 1989: xxxiiixxxv). Self-action identifies self-possessed causal capacity, interaction captures the balancing between forces, and transaction indicates systems of multiple aspects and phases without any independent and final causal capacity. ${ }^{1}$ Assuming that the transactional view of power is central to pragmatism, there are in addition two other types: inter-action or the balancing and exercise of pressures via causal relations or structural mechanisms and self-action in which things or beings act in the own right due to their essence.

At the heart of the pragmatist view of power is the idea of a transactional organization in which aspects or phases of an organic whole can be distinguished but not be separated from an ongoing functioning of a continuous, self-moving social medium. This selforganizing phenomena consists of elements bound together through meaning, intent, signs, and other mentally constructed ways of giving significance to the way agents connect events (Bernstein 1973: 182-3). In this perspective, actors respond to situations and construct their lives in cooperation with others by making their way within transactional, shared, coactive frames of participation.

In contrast to notions of "power over" and "power to," the pragmatist notion is that power arises within and operates through modes of joint participation of human activity. It is the unique role of reason, thought, or ideas in constructing patterns of human action and experience that conceptualizes power as modes through which agents use intelligent judgments to generate substantive consequences. According to Dewey, "The only power the organism possesses to control its own future depends upon the way its present responses modify changes which are taking place in its medium" (MW 10: 15). Dewey continues, "It is all a matter of the way in which its present reactions to things influence the future reactions of things upon it." Further, he adds that this capacity to increase its control lies in "The extent of an agent's capacity for inference, its power to use a given fact as a sign of something not yet given, measures the extent of its ability systematically to enlarge its control of the future." The use of inference highlights the role of individuals 
in shaping the flow of the social dynamic, as mediating agents recognizing and formulating attempting to improve their situation. Active agents rely on inference, involving ideas which connect what happens to what may happen and constituting the effort to control events. This use of inference in the social or political realm is the same as science uses in the constituting knowledge through the discovery and determination of consequences (MW 10: 16). It is this idea of power as "collective intelligence" shaping associated activity and its consequences that provides the unique perspective of pragmatism.

Instead of the press of coercive resources, the constraints and possibilities afforded by structure, or the direction for behavior provided by narratives, power is intrinsic to human praxis because all behavior deals with the consequences of transactions in progress, in operation, partially fulfilled, partially incomplete. For Dewey, praxis emanates from a social partnership and has moral or prospective significance. Dewey writes (MW 14: 16): "Conduct is always shared; this is the difference between it and a physiological process." Combining personal disposition with environmental inducement, influencing future action requires regulating factors, individual or social, guiding future results; action or "habit," such as malice or courage, is the way personal attributes operate in combination with environmental elements. In dealing with problems, praxis involves operations, linking processes to consequences and comparing them to desired ends. The assessment of these operations yields signs of what is happening and what may happen, which becomes "an indispensable factor in behavior dealing with changes, the outcome of which is not yet determined" (MW 10: 15).

Intrinsic participation within trajectories of transactional accomplishing distinguishes the primary mode of making differences. In connecting objective changes and subjective adaptations, habits constitute praxis and carry forward continuity in the adjustment and readjustment of conditions and operations. As Dewey states (LW 13: 18), "The basic characteristic of habit is that every experience enacted and undergone modifies the one who acts and undergoes, while this modification affects, whether we wish it or not, the quality of subsequent experiences. [...] For it is a somewhat different person who enters into them." Habits project the organized and functional nature of internal dispositions; they serve as "a moving force" shaping sensibilities, motivations, and interests which engage the objective and external. Projection, in turn, produces changes in the world, which challenge agents in new ways. If action sequences make for a different person entering into transactions, the effects of past actions make for a slightly different world that is being entered. Dewey writes (LW 13: 22):

Every genuine experience has an active side which changes in some degree the objective conditions under which subsequent experiences take place. The difference between civilization and savagery [...] is found in the degree in which previous experiences have changed the objective conditions under which subsequent experiences take place. ${ }^{2}$

Practical knowledge functions to generate and order social activity. Transactional activity allows subject-matters to develop their own forms of control or regulative functions, testing actions against desired consequences. The application of intelligence through selforganizing criticism implies the possibility of control of future activity. Indirect control, that is, the intrinsic, subjective and intellectual participation of persons in the fabrication of the social medium, combines the way the situation engenders impulses and the way intelligent guides habits that sequence of enveloping socially co-ordinated actions (MW 10: 44). Participation within conjoint activities depends on individuals adjusting internal 
and external factors. Since ideas realize a capacity for inference by signifying connections between actions and effects and between present occurrences and future events, ideas enable individuals to adjust to and control situations in which they take part. Dewey summarizes:

The net outcome of the discussion is that the fundamental means of control is not personal but intellectual. It is not "moral" in the sense that a person is moved by direct personal appeal from others, important as is this method at critical junctures. It consists in the habits of understanding, which are set up in using objects in correspondence with others, whether by way of cooperation and assistance or rivalry and competition. Mind as a concrete thing is precisely the power to understand things in terms of the use made of them; a socialized mind is the power to understand them in terms of the use to which they are turned in joint or shared situations. And mind in this sense is the method of social control. (MW 9: 38)

The practical character of thought and action, furthermore, function to bring about effective accomplishments in accord with the paradigm organizing a social medium. Dewey (LW 13: 22) writes: "The very existence of the social medium in which an individual lives, moves, and has his being is the standing effective agency of directing his activity." The "effective agency" is able to control activity because individuals possess understandings about how to participate in social life, enabling them to gauge the standpoints and behavior of other participants involved in social cooperation. Of education Dewey writes (MW 9: 32), "This other method resides in the ways in which persons, with whom the immature being is associated, use things; the instrumentalities with which they accomplish their own ends." He subsequently illustrates his point:

If a chair is drawn up to a table, it is a sign that he is to sit in it; if a person extends his right hand, he is to extend his; and so on in a never ending stream of detail. The prevailing habits of using the products of human art and the raw materials of nature constitute by all odds the deepest and most pervasive mode of social control. (MW 9: 37)

Moreover, reflective monitoring develops into self-control as the standards by which individuals regulate their actions direct their participation in the social medium (Campbell 1995: 41). Dewey observes:

The individual is held accountable for what he has done in order that he may be responsive in what he is going to do. Gradually persons learn [...] to hold themselves accountable, and liability becomes a voluntary deliberate acknowledgment that deeds are our own, that their consequences come from us. (MW 14: 217)

The interactional and self-actional types of power receive more attention because they are more noticeable than power through social media. Force, authority, or organization dominate when the usual processes of associated action are ignored, breakdown or had never been established. And their descriptions depend on philosophical starting points that fix onto causal givens. Dewey's philosophical method explains these inter-active types of power as the result of a breakdown in the functioning of meanings and intentions controlling social media. External factors are fixed as predominant in determining the balance of pressure and resistance, when a social system fails to coordinate conjoint accomplishments.

These distinctions are brought out in Dewey's discussions of the First World War. In a 1916 article responding to concerns about American entry into World War I, Dewey defended the idea that, contrary to being the equivalent of violence, force was the source of all effects. He writes (MW 10: 248; Hickman 1992: 187) that "[N]o ends are accomplished 
without the use of force." What is needed to stop war, however, is alternative and effective social arrangements for preventing conflicts from taking the form of overt hostilities." To support this argument, he identifies three types of force distinguished by their efficiency: power or self-directed participation, coercive force such as the use of law, and violence or the wasteful application of force. Here identifying power with organized and self-directed activity, Dewey narrows the use of the term power to instances of operations within social media. He maintains (MW 10: 246; see also 211-5), "Power [...] denotes effective means of operation; ability or capacity to execute, to realize ends." That is, power is the effective functioning of a social medium, the intrinsic selfcontrol by agents participating in operating a social apparatus. Coercive force and violence are interactional and rely on external or objective types of control. Dewey observes (MW 9: 31), "When others are not doing what we would like them to or are threatening disobedience, we are most conscious of the need of controlling them and of the influences by which they are controlled."

Interactive models, nonetheless, dominate the literature on power. For example, political science has long held the view that power is a question of who controls in whose interests. Harold Lasswell (1936) famously formulated this question as "Who gets what, when and how?" This conventional view of power, however, presupposes epistemological and objective dualisms, between knowledge and action, facts and values, and elites and led. The result is to focus attention on interactional types of power, prefiguring conclusions confirming domination by the few. Dewey's critical approach to philosophical foundations, further, contends that much conceptualizing of domination is the outcome of the conceptual fixing of the key causal elements determining outcomes. For example, empiricist foundations foreshadow an agency notion of power, realism a dispositional notion, and interpretism a disciplinary notion of power. Various philosophical perspectives specify primary forces that prefigure what power is and how it can be organized. They offer distinct and different insights by privileging diverse metatheoretical foundations or givens. This means that different meta-theoretical starting points interpret phenomena through the lenses of various types of relational phenomena, phenomena seen to involve conflict between interacting elements and to have the prerogative of being the decisive fixed and final factor as the source of causation.

Finally, the self-acting modes of interpreting reality rely on a being's or a thing's own essence as the force propelling changes. This way of thinking can be found in Plato's forms, Hegel's Geist, theological doctrines in which God controls human action. Recently, this mode of thinking resurfaced in the "return of the state" movement in political science, a theoretical trend arguing that the institutional essence of the state should be seen to make it an agent in its own right (Skocpol 1985).

\section{Praxis and the Structure of Power}

The pragmatist analysis of the structure of praxis provides insight into the distribution of power. This focuses on which values control action and how these values shape ways of operating in order to control their effects. In the Quest for Certainty, Dewey writes:

When theories of values do not afford intellectual assistance in framing ideas and beliefs about values that are adequate to direct action, the gap must be filled by other means. If intelligent method is lacking, prejudice, the pressure of immediate circumstance, self-interest and class-interest, traditional customs, institutions of 
accidental historic origin, are not lacking, and they tend to take the place of intelligence. Thus we are led to our main proposition: Judgments about values are judgments about the conditions and the results of experienced objects; judgments about that which should regulate the formation of our desires, affections and enjoyments. For whatever decides their formation will determine the main course of our conduct, personal and social. (LW 4: 211-2)

To analyze the "whatever" allocating control of consequences that Dewey alludes to in the passage above brings out the value-orientations implicated in the habits that actors use within ongoing situations and how these functional processes entail judgments about the desirable. The structure of power, thus, arises from and can be analyzed by examining the ways actors operate to control events. Examining what values control ways of functioning exposes what matters most and for what ends.

Though Dewey did not himself discuss the question of the way praxis distributes control, his conception of the practical character of thought and action offers tools for clarifying the way the elements of praxis operate to pattern coordinated operations and control effects. Here again the three overlapping circles of analysis - inquiry, experience, and social media - come into play.

The first element, the social elements of custom and habit, involves analyzing how social media establish interests and, in turn, how individual motive selects a specific environment and offers appropriate responses. The practical character of knowledge means that motives and practices of activity are neither given by external authority nor permanently fixed (see Dewey 1929). They depend on the inheritance of historical circumstances and dynamics within which an agent's internal capacities adjust to external circumstances. Working from a pragmatist tradition, C. Wright Mills expresses this idea in his discussion of the cultural apparatus. He writes: "Every man interprets what he observes - as well as much that he has not observed: but his terms of interpretation are not his own; he has not personally formulated or even tested them" (Mills 1967: 406). Dewey's effort to shift analysis away from first principles, foundational concepts, or fixed truths establishes the need to examine the use and adaptation of the medium. Rather than being subordinated to the purely subjective or an independent reality, experience is a matter of the transaction of a living being within its environment, the ways the objective world affects human action and is in turn modified by it.

Instead of relying on first principles and reified causal forces such as wealth or weapons, Deweyan analysis suggests that the basis of action be located through empirical and intellectual scrutiny of cultural tools conditioning experience. The use of these cultural tools or habits operates in the unfolding of trajectories within a medium. For Dewey, habits "assimilate objective energies, and eventuate in command of environment" (MW 14: 15-6). Habits for Dewey reflect prior activity, provide an ordering of elements for action, are projective and dynamic, and are operative in making activity manifest (MW 14: 31). They also give form to stages in a sequence of ordering a situation through craftsmanship. They appear analogous to the operative character of the developmental patterns identified by Jean Piaget's concept of schema, the self-organizing projections which a child uses to assimilate the world and which undergo reorganization or accommodation in response to that world (Piaget 1963). Tom Burke interestingly offers an innovative suggestion for a way of analyzing the operation of the cultural apparatus. He proposes that universal propositions, one of Dewey's logical modes, can be used to analyze ideology or systems of ideas and how they function in social life (Burke 2004). Applying this insight suggests that Dewey's concept of habit may be characterized in 
terms of his own conception of the types of logical propositions and the way they operate to fashion a cultural medium. Such a project may aid in clarifying links between operations and effects, even facilitating in formulating the way connections between conditions and consequences may yield desirable results. In short, a first step in unpacking structures of praxis and power must be to examine the logical operations or habits by which the subject-matter of an existing social medium prescribes and projects norms and ends and how these include or exclude, privilege or deprive, the particular interests comprising the conditions within which agents operate.

A second element follows from Dewey's understanding of experience, analyzing the ways agents respond to and endure their media. This locates agency within cultural toolkits and appreciates its transactional dynamics, identifying initiative in deciding problems and possible responses. By implication, this view rejects the dualism of agency and structure central to current debates about power; instead, it offers the view that there is only human praxis and that action generates effects that are often reified and taken as structural forces in their own right. Dewey's emphasis on the insurgent and creative character of human action means that experience involves projection via habits into circumstances not fully known; it is experimentation for the purpose of connecting with the future. As human actors undergo a circumstance, they simultaneously attempt to control it.

Pragmatism further emphasizes the rebellious, projective and educative nature of human experience, while rejecting simple and mechanical causal relations between independent units. For Dewey, individuals are "live creatures," never totally passive (LW 10: 9-25). Their experience involves "simultaneous doings and sufferings." As Dewey writes (1917: 8), "The most patient patient is more than a receptor. He is also an agent - a reactor, one trying experiments, one concerned with undergoing in a way which may influence what is still to happen." Dewey continues (MW 10: 9), "Our undergoings are experiments in varying the course of events; our active tryings are trials and tests of ourselves." As a living organism, individuals strive to turn their circumstances into sustenance aiding their life prospects. Analyzing the way agents use things to operate within the dynamic and interdependent relations of specific situations, then, reveals the loci of initiative within the media and the craftsmanship of agents in functioning to sustain complex systems of cultural operations.

41 A third element in analyzing the distribution of power, the criterion of decision, involves the role of inference and judgment in transforming problems into consequences. Dewey (MW 2: 296) proposes that reality is remade through the doubt-inquiry-judgment process, which functions through experience in accordance with the test of consequences and for the purpose of "readjusting and expanding the means and ends of life." Thinking projects possible consequences or solutions through the interpretation of events (MW 10: 15-6). In so doing, thinking concludes with a conjecture which serves as the criterion determining conduct transforming a questionable situation. Judgment selects and applies a standard or rule of operation that terminates a problematic situation and creates an existential unity (Burke 1994: 109). Dewey writes in How We Think (LW 8: 215), "The judgment when formed is a decision [his emphasis]; it closes, or concludes, the question at issue." Resolving problematic situations requires action transforming objective circumstances, the application of inquiry's results in devising a more effective link between the difficulty and the desired effects. 
Significantly, acts of judgment producing transforming differences are both instrumental and consummatory. They are instrumental because they facilitate the achievement of desired ends through coordination and control of collective accomplishment. And they are consummatory because power relations promote communication, a "sharing in the objects and acts precious to a community, a sharing whereby meanings are enhanced, deepened and solidified in the sense of communion" (LW 1: 159).

The connection between the instrumental, substantive, and consummatory values and qualitative situations affects the way judgments operate. When instrumental, "intelligence is partial and specialized, because communication and participation are limited, sectarian, provincial, confined to class, party, professional group" (LW 1: 159). When bureaucratic organization, the imperatives of technical necessity, or the privileging of rational self-interest become uppermost, action is mechanical and self-indulgent. Absolutes or externally divined duty also denies participation.

In short, the analytical elements of Dewey's theory of praxis identify how the distribution of social control varies, the way operations affect who decides what and how and so constitute a medium controlling participation and effects. While the theory of praxis and power frame a transactional description of activity, it also facilitates the analysis of patterns of control in interactional and self-actional modes of praxis. Whatever the type of social conjunction, examining how values shape its modes of operating illuminates the substantive consequences of what gets done.

\section{Consequences For Conceptualizing Power}

The transactional conception contrasts with interactional characterizations of power, namely, "power over" and "power to," that dominate the current literature. Agency and structuralist formulations attribute the generation and exercise of power to the balance of resources, consent, traditions, or institutions. In the "faces of power" debate, power resides with agents who are equipped with various armaments giving them control of the agenda and/or decision-making. Structuralists locate the control of interests and decisions in objective institutional constraints and mechanisms. As Hay (2002: 185) states: "Power then is about context-shaping, about the capacity of actors to define the parameters of what is socially, politically and economically possible for others." Foucault locates power in a cultural entity he calls disciplinary knowledge, itself an expression of power. It also contrasts with self-actional descriptions of difference making. Each of these identifies power as the result of external imposition.

Dewey's transactional conception of praxis informs a view of power centering on the ways agents compose and operate within evolving social media. Power arises from intellectual control of participation in conjoint association and it the distribution of control depends on the purposes animating the flow linking agent and environment into modes of activity. Dewey would agree with Hannah Arendt's assertion in that "Power is never the property of an individual; it belongs to a group and remains in existence only so long as the group keeps together" (Arendt 1969: 137), though he would emphasize that a group is itself a creation of the value-laden and knowledgeable praxes of its members. This means that control inheres in the values directing the flow of actions forming the social apparatus. 

emphasizes the crucial role of the agency of human actors and their use of ideas and habits to control conduct as they construct and reconstruct activities moving them through life. In patterning interactions actors use ideas and habits as practical guides to particular consequences, as the tools for constituting social co-operation. Changing the social expectations agents use to hold themselves accountable for their behavior redefines the way things get done. As understandings directing activity, ideas are operative predispositions. The practical effect is to establish the accountability that controls conduct in particular contexts. Further, because transactions are dynamic and contingent applications of operations to social situations, power is created, variable, and tentative as agents conjointly engage in transactions arising from changing problems. Not fixed and given, variation in structure occurs as agents respond to their situations, for example, the fading of a honeymoon phase of a newly elected US President. Thus, power is intrinsic to human conduct, since inquiry and judgment afford control of ways of acting on and with things and the differences made. ${ }^{3}$ a thing or essence with causal force, challenging the structure versus agency debate so prominent in the social science literature. The transactional view dispels the philosophical realist notion that agents are mere bearers of the interests of institutions and that power lies in controlling institutional incentives as well as the critical realist contention that structure is the medium and result of agency. The pragmatist views these notions of structure as examples of the interactional models' reliance on reifying and fixing analytic categories.

A second implication is that the centrality of experience to praxis means that individuals have a degree of autonomy in affecting change. Action that is informed and deliberate is intelligent, projecting desirable effects and checking their results. This enables human beings to control the quality of their future experience (Thayer 1968: 200). As adaptive behavior, the intelligent use of ideas through the scrutiny of consequences makes possible more fruitful and desirable experience (LW 1: 17). Therefore, intelligence, inquiry, and ideas enable individuals to make a difference to themselves and to the contexts in which they operate. About his pragmatism, Dewey writes that it brings "into prominence the importance of the individual [...] [for] It is he who is the carrier of creative thought, the author of action, and of its application" (LW 1: 20). Human beings are participants and experimenters in organic processes, including a community of inquiry. According to Dewey (LW 1: 20), "The individual mind is important because only the individual mind is the organ of modifications in traditions and institutions, the vehicle of experimental creation." Relatively autonomy, then, stems from human praxis and the self-reflection guiding participation in social processes responding to changing environments.

The autonomy afforded by praxis means further that questions of values and justice are crucial. By turning conditions into consequences, ideas operationalize values; they give expression to what is regarded as worthy. Action requires taking the responses of others into account and having one's actions taken into account. Social transactions rely on and produce socially regulated behavior. To make a moral judgment is to decide "whether what is good in immediate experience has consequences for latter experience that warrant accepting the immediate good as a true good" (Rockefeller 1991: 407). Inquiry into the desirable or undesirable influences the character or habits of the inquirer and 
requires the application of a standard of judgment that actualizes priorities (Kennedy 1970: 87-90).

51 The pursuit of objectives through a social medium means that power, in addition, involves efficiency in operating. The organization of energy into social media increases working efficiency. ${ }^{4}$ Dewey observes, "Nevertheless force is efficient socially not when imposed upon a scene from without, but when it is an organization of the forces in the scene" (MW 10: 215). The more efficiently power operates the less external, violent force will be relied upon. Moreover, the more direct power is, the more it is open to public controversy. Since direct control operates in a more exposed arena, it incites further coercion in order to suppress emerging conflict. Contrary to an empiricist worldview in which agents engage in overt tests of strength and imposition, the efficient achievement of ends depends on organizing the way individuals coordinate their own actions within the larger project of collective accomplishment. And pragmatism's interest in efficiency assumes that consequences regulate power rather than, as with Nietzsche and Foucault, power itself determining fact and truth (Weberman 1995).

Finally, the transactional conception of praxis and power exemplifies a method of critical analysis for deconstructing power structures. It makes evident that ideologies rely on political rhetoric or metaphor functioning to blind us to the ways their theoretical starting points entail power and effects. This critical function is important to creative democracy, based on challenges to and judgment about the use of power for common good and growth (Hildred 2009: 794-6, 799). More generally, pragmatism's empirical method provides a tool for critically "seeing" the antecedently fixed assumptions empowered to produce the theoretical and empirical outcomes in modern research schools, providing a system for examining how their philosophical assumptions prefigure their models of power. In Experience and Nature, Dewey recounts this critical analytical method, namely, the philosophical fallacy, as a way of unmasking the effects of theoretical starting points (LW 1: 10-41). By taking antecedent givens as foundations, Dewey argues, theorists prefigure how and what they find. This meta-philosophical tool calls for the identification of assumptions that prefigure representations of nature and their effects and suggests that their illumination provides for their control. Dewey's empirical method, in particular, asks how meta-theory frames the way actors justify their activity, gain initiative, and are held accountable to what they value, that is, how philosophical givens prescribe the 'desired' perception and interpretation. This idea, that what we see is attributable to our own ways of experiencing things, can be used to analyze models of power in political ideologies as well as theoretical approaches (Wolfe 2011: 138). Further, as articulated in Reconstruction in Philosophy, it challenges social theory's preoccupation with debating and refining notions about its tools of inquiry instead of solving concrete problems (Ratner 1939: 63). Even more, this critical capacity to deconstruct power phenomena suggests a way of giving meaning to the concepts of subjective and real interests by the exposure of modes and structures of power (Amit 2008). The pragmatist critique thus enables us to get beyond a political theory's claims to represent reality and instead to examine how its initial conceptual categories imply consequences for the way relations of control ought to be exercised. 


\section{Conclusion}

In rejecting the philosophical starting points underlying the empiricist agency, realist dispositional or structuralist, and interpretist facilitative models of power, Deweyan pragmatism provides a theory of praxis that is a tacit theory of power. This offers an indirect or transactional view of the ways human praxis makes differences within and through a social medium. A social medium, such as a class or game, carries power in its collective consequences in shaping conditions reacting on agents. It also is a framework of control since participants require understanding about how it operates and selfcontrol in their application of knowledge in order to bring the social medium into being. This view holds that the social medium is the primary mode through which differences are made. Yet, if indirect control through the social medium breaks down, direct control through various types of relational enforcement occurs. In other words, Deweyan pragmatism recognizes that power also operates through inter-actional modes, such as, force, unequal resources, public consent, law, a generalized capacity, expertise, or a structural property of institutions. Further, different forms or patterns within social media represent different distributions of control. These depend on the ways different social paradigms motivate and inform praxis, how different experiences enable agents to use their range of options to take initiatives within these frameworks, and what valueorientations control judgments. The resulting variations in the type and form of conduct, finally, provide a means for improving the quality of future events.

\section{BIBLIOGRAPHY}

AMIT R., (2008), “Power: A Pragmatist, Deliberative (and Radical) View," Journal of Political Philosophy, 16 (3), 272-92.

ARENDT H., (1969), "From On Violence," in Haugaard M. (ed.), (2002), Power: A Reader, Manchester, Manchester University Press.

BAERT P., (2003), “Pragmatism, Realism and Hermeneutics," Foundations of Science, 8 (1), 89-106.

BERNSTEIN R. J., (1971), Praxis and Action: Contemporary Philosophies of Human Activity, Philadelphia, University of Pennsylvania Press.

BURKE T., (1994), Dewey's New Logic: A Reply to Russell, Chicago, University of Chicago Press.

BURKE T., (2004), “The Logical Necessity of Ideologies," in Khalil E. (ed.), Dewey, Pragmatism, and Economic Methodology, London, Routledge.

CAMPBELL J., (1995), Understanding John Dewey: Nature and Cooperative Intelligence, Chicago, Open Court.

CLEGG S., (1989), Frameworks of Power, London, Sage.

CLEGG S. \& M. HAUGAARD (eds.), (2009), The Sage Handbook of Power, London, Sage. 
COHEN I., (2000), “Theories of Action and Praxis," in Turner B. S. (ed.), The Blackwell Companion to Social Theory, Malden, MA, Blackwell Publishers.

DAHL R., (1968), “Power,” in Haugaard M. (ed.), (2002), Power: A Reader, Manchester, Manchester University Press.

DEWEY J., (1903), Studies in Logical Theory, in Essays in Logical Theory 1902-1903, The Middle Works of J. Dewey, 1899-1924, vol. 2 (MW 2), ed. by J. A. Boydston, Carbondale and Edwardsville, Southern Illinois University Press, 1976.

DEWEY J., (1916), Democracy and Education, The Middle Works of J. Dewey, 1899-1924, vol. 9 (MW 9), ed. by J. A. Boydston, Carbondale and Edwardsville, Southern Illinois University Press, 1980.

DEWEY J., (1916), "Force and Coercion," in Essays on Philosophy and Education 1916-17, The Middle Works of J. Dewey, 1899-1924, vol. 10 (MW 10), ed. by J. A. Boydston, Carbondale and Edwardsville, Southern Illinois University Press, 1985.

DEWEY J., (1916), "Force, Violence and Law," in Essays on Philosophy and Education 1916-17, The Middle Works of J. Dewey, 1899-1924, vol. 10 (MW 10), ed. by J. A. Boydston, Carbondale and Edwardsville, Southern Illinois University Press, 1985.

DEWEY J., (1917), “The Need for a Recovery of Philosophy," in Essays on Philosophy and Education 1916-17, The Middle Works of J. Dewey, 1899-1924, vol. 10 (MW 10), ed. by J. A. Boydston, Carbondale and Edwardsville, Southern Illinois University Press, 1985.

DEWEY J., (1922), Human Nature and Conduct, The Middle Works of J. Dewey, 1899-1924, vol. 14 (MW 14), ed. by J. A. Boydston, Carbondale and Edwardsville, Southern Illinois University Press, 1983.

DEWEY J., (1925), Experience and Nature, The Later Works of J. Dewey, 1925-53, vol. 1 (LW 1), ed. by J. A. Boydston, Carbondale and Edwardsville, Southern Illinois University Press, 1981.

DEWEY J., (1925), "Development of American Pragmatism," in Essays, The Public and Its Problems, The Later Works of J. Dewey, 1925-53, vol. 2 (LW 2), ed. by J. A. Boydston, Carbondale and Edwardsville, Southern Illinois University Press, 1984.

DEWEY J., (1927), The Public and Its Problems, The Later Works of J. Dewey, 1925-53, vol. 2 (LW 2), ed. by J. A. Boydston, Carbondale and Edwardsville, Southern Illinois University Press, 1984.

DEWEY J., (1929), The Quest for Certainty, The Later Works of J. Dewey, 1925-53, vol. 4 (LW 4), ed. by J. A. Boydston, Carbondale and Edwardsville, Southern Illinois University Press, 1984.

DEWEY J., (1933), How We Think: A Restatement of the Relation of Reflective Thinking to the Educative Process, The Later Works of J. Dewey, 1925-53, vol. 8 (LW 8), ed. by J. A. Boydston, Carbondale and Edwardsville, Southern Illinois University Press, 1986.

DEWEY J., (1934), “Live Creature," in Art as Experience, The Later Works of J. Dewey, 1925-53, vol. 10 (LW 10), ed. by J. A. Boydston, Carbondale and Edwardsville, Southern Illinois University Press, 1987.

DEWEY J., (1938), "Criteria of Experience," in Experience and Education, The Later Works of J. Dewey, 1925-53, vol. 13 (LW 13), ed. by J. A. Boydston, Carbondale and Edwardsville, Southern Illinois University Press, 1988.

DEWEY J. \& A. BENTLEY, (1949), Knowing and the Known, The Later Works of J. Dewey, 1925-53, vol. 16 (LW 16), ed. by J. A. Boydston, Carbondale and Edwardsville, Southern Illinois University Press, 1989. 
DIGGINS J., (1994), The Promise of Pragmatism: Modernism and the Crisis of Knowledge and Authority, Chicago, University of Chicago Press.

DICKSTEIN M. (ed.), (1998), The Revival of Pragmatism: New Essays on Social Thought, Law and Culture, Durham and London, Duke University Press.

GARDNER H., (1985), The Mind's New Science, New York, Basic Books

GIDDENS A., (1984), The Constitution of Society: Outline of the Theory of Structuration, Berkeley and Los Angeles, University of California Press.

HAUGAARD M. (ed.), (2002), Power: A Reader, Manchester, Manchester University Press.

HICKMAN L., (1992), John Dewey's Pragmatic Technology, Bloomington, Indiana University Press.

HILDEBRAND D., (2003), Beyond Realism and Anti-Realism: John Dewey and the Neopragmatists, Nashville, Vanderbilt University Press.

HILDEBRAND D., (2008), Dewey: A Beginner's Guide, Oxford, Oneworld.

HILDRED R., (2009), “Reconstructing Dewey on Power,” Political Theory, 37 (6), 780-807.

JACKSON P., (2006), "John Dewey," in Shook J. R., Margolis J. (eds.), A Companion to Pragmatism, Malden, MA, Blackwell Publishing.

JOAS H., (1998), "The Inspiration of Pragmatism: Some Personal Remarks," in Dickstein M. (ed.), The Revival of Pragmatism: New Essays on Social Thought, Law, and Culture, Durham and London, Duke University Press.

JOAS H., (1996), The Creativity of Action, Chicago, University of Chicago Press.

Foucault M., (1979), Discipline and Punish: the Birth of the Prison, New York, Vintage.

JoHnson M., (2010), “Cognitive Science and Dewey's Theory of Mind, Thought, and Language," in Cochran M. (ed.), The Cambridge Companion to Dewey, Cambridge, Cambridge University Press.

JUnG M., (2010), “John Dewey and Action,” in Cochran M. (ed.), The Cambridge Companion to Dewey, Cambridge, Cambridge University Press.

KENNEDY G., (1970), “Dewey's Logic and Theory of Knowledge," in Boydston J. A. (ed.), Guide to the Works of John Dewey, Carbondale and Edwardsville, Southern Illinois University Press.

LASSWELl H., (1936), Politics: Who Gets What, When and How, New York, McGraw-Hill.

LAVINE T., (1989), "Introduction," in Knowing and the Known, The Later Works of J. Dewey, 1925-53, vol. 16 (LW 16), ed. by J. A. Boydston, Carbondale and Edwardsville, Southern Illinois University Press. MILLS C. W., (1967), “The Cultural Apparatus,” in Horowitz I. L. (ed.), Power, Politics, and People: The Collected Essays of C. Wright Mills, London, Oxford University Press.

MANCIAS P., (1998), “John Dewey and American Social Science," in Hickman L. (ed.), Reading Dewey: Interpretations for a Postmodern Generation, Bloomington and Indianapolis, Indiana University Press.

PIAGET J., (1963), The Origins of Intelligence in Children, New York, W.W. Norton. RABINOW P., (1984), "Introduction," in Rabinow P. (ed.), The Foucault Reader, New York, Pantheon. RATNER J., (1939), “Dewey's Conception of Philosophy,” in Schilpp A. (ed.), The Philosophy of John Dewey, Evanston, Northwestern University. 
ROCKEFELLER S., (1991), John Dewey: Religious Faith and Democratic Humanism, New York, Columbia University Press.

RORTY R., (1979), Philosophy and the Mirror of Nature, Princeton, Princeton University Press.

ROUSE J., (1994), “Power/Knowledge," in Gutting G. (ed.), The Cambridge Companion to Foucault, New York, Cambridge University Press.

RUCKER D., (1977), "Introduction," in Dewey J., Essays, The Middle Works of J. Dewey, 1899-1924, vol. 3 (MW 3), ed. by J. A. Boydston, Carbondale and Edwardsville, Southern Illinois University Press.

SKOCPOL T., (1985), "Strategies of Analysis in Current Research," in Evans P., Rieschemeyer D. \& Skocpol T. (eds.), Bringing the State Back In, Cambridge, Cambridge University Press, 1985.

SLEEPER R. W., (2001), The Necessity of Pragmatism: John Dewey's Conception of Philosophy, Chicago, University of Chicago Press.

STOKER G., (2010), "Introduction to Part I," in Marsh D. \& Stoker G. (eds.), Theory and Method in Political Science, 3rd edition, Basingstoke, UK, Palgrave Macmillan.

THAYER H. S., (1968), Meaning and Action: A Critical History of Pragmatism, Indianapolis, BobbsMerrill.

WEBER M., (1958), From Max Weber: Essays in Sociology, H. Gerth \& C. W. Mills (eds.), New York, Oxford University Press.

WEBERMAN D., (1995), “Foucault's Reconception of Power," Philosophical Forum 26, 3.

wolfe A., (1998), “The Missing Pragmatic Revival in American Social Science," in Dickstein M.

(ed.), The Revival of Pragmatism: New Essays on Social Thought, Law, and Culture, Durham and London, Duke University Press.

WOLfE J., (2002), “Power: A Pragmatist Proposal,” Studies in Symbolic Interaction 25, 303-24.

WOLFE J., (2011), "Who rules the EU? Pragmatism and power in European integration theory," Journal of Political Power, 4 (1), 127-44.

\section{NOTES}

1. There are parallels between the Dewey and Bentley categories of description and action and C. S. Pierce's categories of Firstness (givenness), Secondness (balance of pressures or forces), and Thirdness (expressions of meaning and intention through triadic linkages between agent, sign, situation) (Bernstein 1971: 177-87).

2. Tom Burke (1994: 39) characterizes continuity as linking two "orthogonal" dimensions: 1) static and dynamic and 2) internal and the external.

3. The view that power is productive and ubiquitous is also found in the work of Anthony Giddens 1984, and Michel Foucault 1979.

4. This pragmatist view shares a concern for efficiency with Machiavelli and Foucault. See Clegg (1989: chapters 2, 7), Rabinow 1984, Rouse 1994. 


\section{ABSTRACTS}

Asking if pragmatism, and John Dewey in particular, has a theory of power poses the question about the intellectual resources that pragmatism has to offer the social sciences. Pragmatism stands accused of being naïve about power and presenting the specter of an overly soft program for doing social science. Yet, Dewey's philosophical method provides a distinctive transactional theory of power and untapped resources for advancing social science. Dewey's melioristic philosophical vision develops a theory of praxis that is a tacit theory of power. Explicating his concerns with experience, inquiry, and social life show how they converge into his theory of praxis and power. Developing this theory, next, enables distinctions to be outlined between Dewey's transactional view of power and the mainstream interactional view seen in the work of Dahl, Lukes, and Mann. Furthermore, the theory of praxis establishes analytical categories for deconstructing the structure of transactional power, the patterns or modes of conjoint activity. Dewey's pragmatist theory of power stands in marked contrast to interactional models and provides the analytical tools for the critical assessment of power.

\section{AUTHOR}

\section{JOEL WOLFE}

Department of Political Science, University of Cincinnati

Joel.wolfe[at]uc.edu 